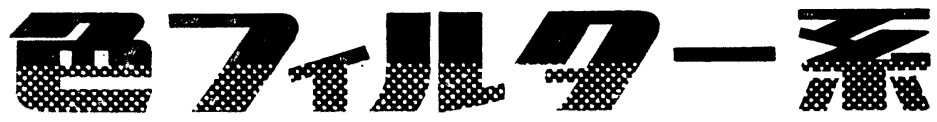

\title{
Color Filter Series
}

\section{小西六写真工業株式会社化学研究所 馬 場 輝 郎}

写真撮影のみに止らず広く実験に使用される色フィル ターには多くの種類があるが, 現在比較的多く用いられ ているものは Wratten フィルター系など幾つかのもの に限られている。フィルターを使用の目的に応じて選択 するためにはその分光特性等をはっきり知っていなけれ ばならないが，これらの值は整理されたものでまとまっ たものがなかなか見当らない。筆者の研究室では使用者 としての立場からいくつかのフィルター系について分光 透過率值怙よび測色值をまとめたので，この值をここに 提供してカラーテレビ研究のためにいくらかでも御役に 立てば幸と考える。

整理したフィルター系としては次のようなものがある。

1. ゼラチン・フィルター

Wratten Light Filters (E. K.)

コニ・ゼラチン・フィルター系 (小西六)

2. ソリッド・ガラス・フィルター

マッダ・ソリッド・ガラス・フィルター（東芝）

Corning Glass Filters (Corning)

Jenaer Farb-und Filterglas (Schott)

以上のものについて $10 \mathrm{~m} \mu$ 打きの透過率值, 分光透 過曲線, I.C.I. のAおよびC光源についての測色計算値 を示すことにする。これらの值は各メーカーで発表して いる分光透過率特性を基とし, 不足の分は当研究室で測 定の上, $10 \mathrm{~m} \mu$ 間隔重価坐標法により色度値を求めた ものである。

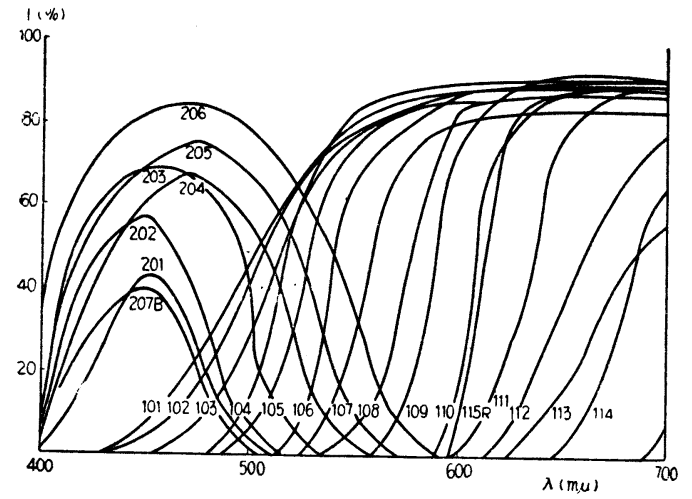

第1図 \#101 115 R は長波側を透過し短波側を透過しないもので, 101 のうすい黄から黄, 黄赤をへて114のくらい赤に至る。200 番台は 全部青一青緑の色をもち曲線の右側の長波の光を透過しない。

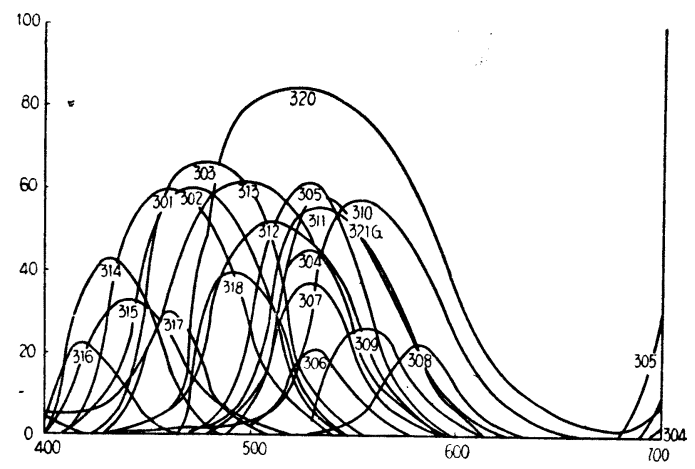

第 2 図 \#301 321 G は図の如く山形の透過率特性をすち両端の青お よび赤の光を透過しない。色は!316 の青から 311 辺りの緑をへで308で は黄となつている。

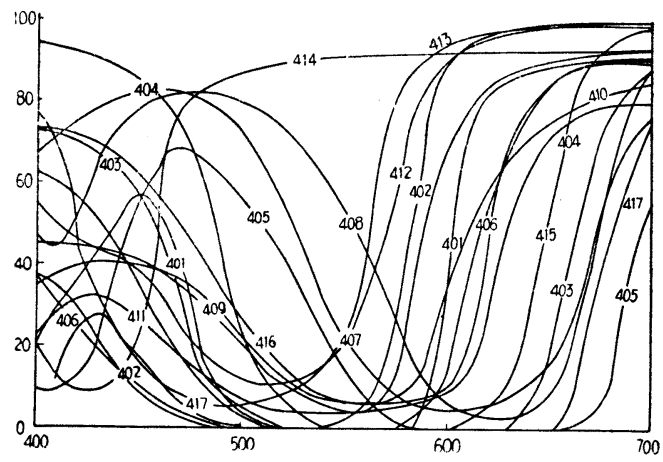

第 3 図大体青および赤の 両端波長部分を透過するもので色は青紫一 赤紫一赤となつている。

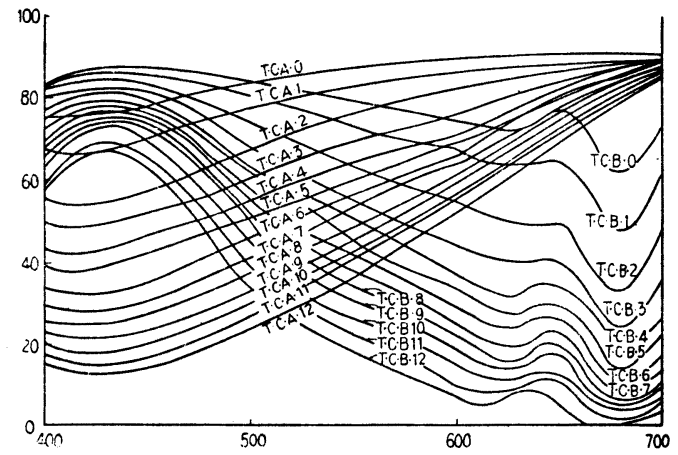

第 4 図一般にい弓色温度荾換フィルターでAはアンバー, B は青て

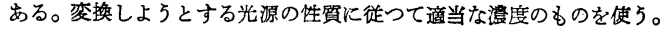




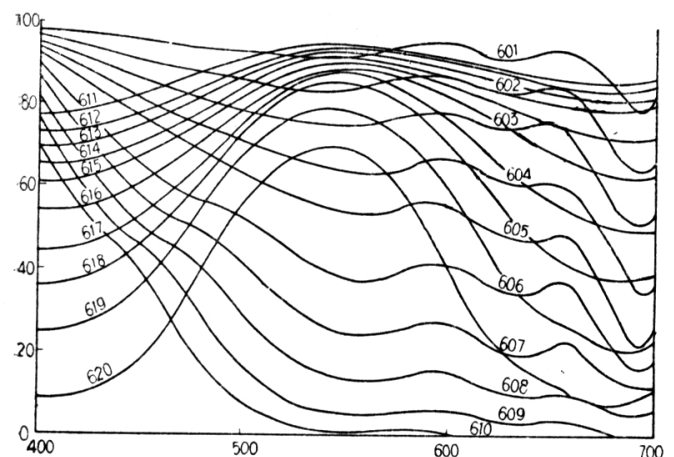

第 5 図青, 緑, 赤, シアン, マゼンタ, 黄の各種の眐度のもので青々 緑を示す。

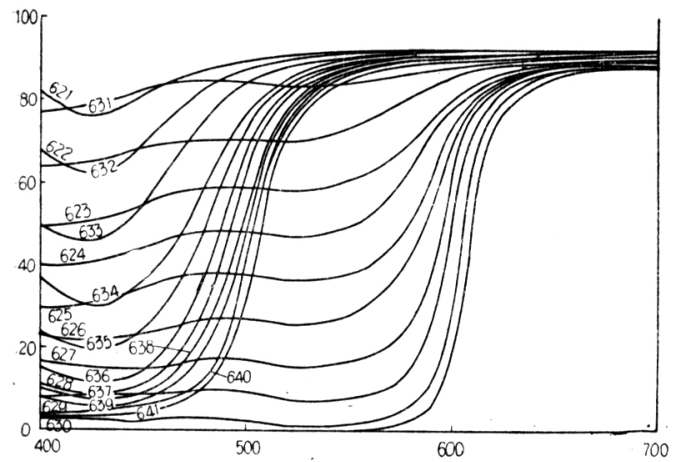

第 6 図青, 緑, 赤, シアン, マゼンタ, 黄の各種の漫度のもので赤と 黄在示守。

以下各々の透過率曲線を示す（透過率值沶よび色度值 は紙面の関係上からこれを省略する)。

1. コンゼラチン フィルター系

平面ガラスに色素ゼラチン膜を塗布したものであって， ガラス厚みは各使用目的に応じて 1〜 5 mm のものを使 用している。

全部で 10 小系列に分類してあって，その各々は

i.（100 番台）長波透過短波吸収の赤一黄であり, シャープカット・フィルター

ii.（200 番台）短波透過長波吸収の青でシャー プカット・フィルター

iii.（300 番台）山型の透過率曲線をもつ青緑一 緑でパンド透過フィルター

iv.（400 番台）各型の透過率曲線を\&つ青紫一 赤紫でバンド吸収フィルター

v. (500 番台) カラーフィルム撮影用のエネルギ 一变換执よび色補正フィルター

vi. (600 番台) カラーフィルム焼付を主な目的と する青, 緑, 赤, シアン, マゼンタ, 黄の色補正フィルター vii. (700 番台) 中性灰色フィルター viii. (800 番台) 単色フィルター

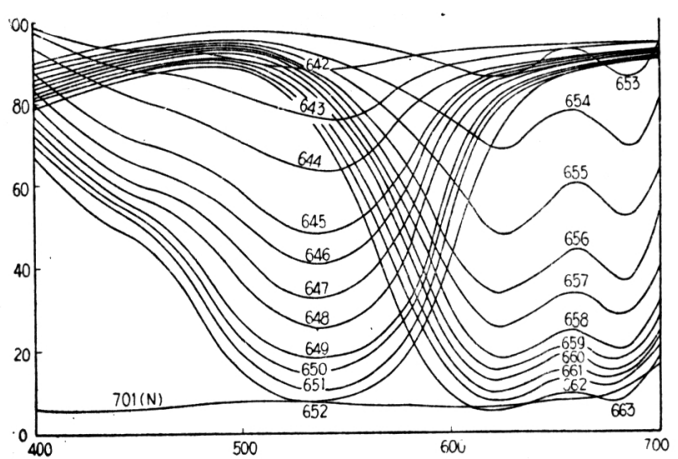

第 7 図青, 緑, 赤, シアン, マゼンタ, 黄の各種の滇度のものでマゼ ンタとシアンを示す。

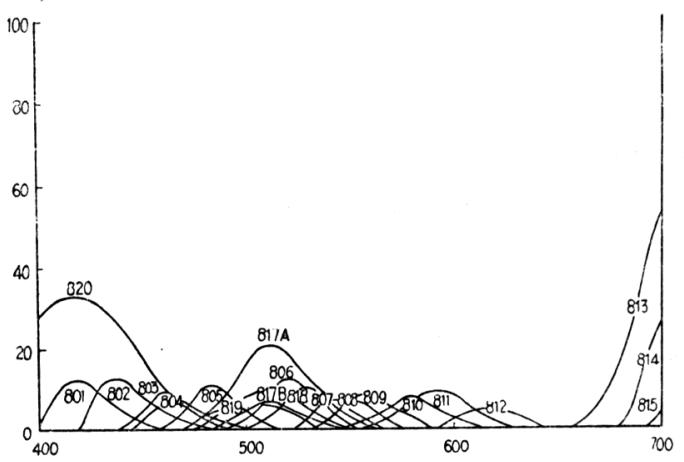

第 8 図 単色フィルターで 801 の青から 806 で緑, 815 のくらい赤に 至つている。

ix. (900 番台) 紫外線用フィルター（未完成）

x. (1000 番台) 赤外用フィルター

以上のごとくである。他に腤室用安全フィルター系が あるが省略する。

第 1 〜 図は各々の透過率曲線である。

(昭和 29 年 11 月 15 日受付)

\section{筆者の横顔}

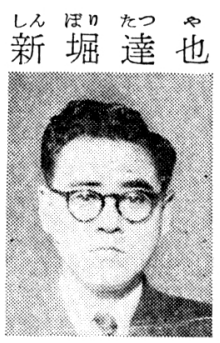

昭和 16 年 12 月東大工学部電 気工学科卒業。同 20 年まで海軍 技研江心打有綄通信関係の研 究に彷事。21年 4 月大阪搬送電 気通信工事局勤務, 以来大阪总 信局, 電気通信省施設局, 霞々 公社資材局勤務光経て，現在通 研基礎部伝送研究課々長補佐。

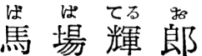

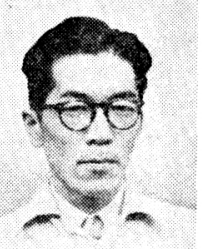

眧和 20 年 9 月東京大学第一工学 部応用化学科卒業。昭和 21 年 6 月 小西六写真工業株式会社入社, 化 学研究所勤務。ついで本社技術 室, 日野工場品資管理室勤務を経 て現在同化学研究所第 9 研究室主 任。零分散光電分光光度計関与 る研究で昭和 28 年度映画技術坫 会賞を受く。 